\title{
Partnerschap met gezinnen in armoede op beleids- of programmaniveau
}

\author{
Barbara Groot · Angela Nijland-Turel · Sanne Waagen · Tineke Abma
}

Geaccepteerd op: 1 juni 2021 / Published online: 14 juli 2021

(C) The Author(s) 2021

Samenvatting Mensen in armoede worden steeds vaker actief betrokken bij projecten in gemeenten en zorg- en welzijnsinstellingen. Meepraten op beleidsen programmaniveau is echter minder vanzelfsprekend. Gezondheidsfonds FNO experimenteerde de afgelopen jaren met het betrekken van moeders in een achterstandssituatie bij het programma Gezonde toekomst dichterbij. Er waren twee hoofddoelen: het ontwikkelen van beter aansluitende activiteiten én bijdragen aan het empoweren van de doelgroep. In dit artikel geven we een antwoord op de vraag of deze doelen zijn bereikt en wat is geleerd over manieren waarop je de stem van gezinnen hoorbaar kunt maken. We hopen dat dit artikel andere fondsen, beleidsmakers en programmamanagers inspireert bij het vormgeven van hun participatiebeleid. We bieden handvatten om die uitdaging aan te gaan.

Trefwoorden participatie $\cdot$ burgerparticipatie cocreatie $\cdot$ armoede $\cdot$ gezondheidsachterstanden

Digitaal aanvullende content De online versie van dit artikel (https://doi.org/10.1007/s12508-021-00307-w) bevat aanvullend materiaal, toegankelijk voor daartoe geautoriseerde gebruikers.

\section{B. Groot · Prof. dr. T. Abma}

Amsterdam Public Health Instituut, Amsterdam UMC, locatie VUmc, Amsterdam, Nederland

A. Nijland-Turel $(\bowtie)$

FNO Zorg voor Kansen, Amsterdam, Nederland

Angela.nijland@fnozorgvoorkansen.nl

\section{S. Waagen}

FNO Klankbordgroep Gezonde Toekomst Dichterbij,

Amsterdam, Nederland

Prof. dr. T. Abma

Leyden Academy on Vitality and Aging, Leiden, Nederland

\section{Partnership with families in poverty at the policy or program level}

Abstract Nowadays, people who live in poverty are more actively involved in projects in municipalities, care and welfare institutions. However, participation at the level of policy and program is less evident. Equity fund FNO aims to work in a participatory fashion. Therefore, FNO experimented with user-involvement in their program 'Towards a Healthier Future' over the past years. But how do you give voice to families in vulnerable situations? And what are the benefits? This article describes the process of developing partnerships with people who live in vulnerable situations in the program and the value for all involved. We hope that this article offers insights to join us in this participatory turn.

Keywords participation - user-engagement - cocreation $\cdot$ poverty $\cdot$ health literacy

\section{Hoe zorg je ervoor dat mensen in een achterstandssituatie participeren?}

In de (geestelijke) gezondheidszorg en binnen het welzijnswerk is de afgelopen jaren veel praktijkervaring opgedaan met het samenwerken met bewoners in een achterstandssituatie. Te denken valt aan rollen als vrijwilligers, ambassadeurs en ervaringsdeskundigen. Ook op beleidsniveau werken veel organisaties met formele cliënten-, burger-, Wmo- en participatieraden. Vaak blijken deze vormen niet goed aan te sluiten op de leefwereld en mogelijkheden van mensen in een achterstandssituatie [1-3]. Hoe kunnen mensen met een lager opleidingsniveau dan wel goed participeren op beleidsniveau?

Het thema 'participatie van de doelgroep' is een van de uitgangspunten van FNO. De achterliggende 


\section{Wat is FNO?}

FNO is een vermogensfonds dat uitgaat van het idee dat een kwetsbare gezondheid een volwaardig leven niet in de weg mag staan. Het programma Gezonde toekomst dichterbij werkte van 2015 tot 2020 aan het verminderen van gezondheidsachterstanden van gezinnen in achterstandssituaties. In de 46 projecten binnen dit programma is ook veel geleerd over het samenwerken met bewoners [9, 10]. Samen met alle partners wil FNO duidelijk maken dat investeren in mensen loont, ook op het vlak van gezondheid. Zie: https://www.fnozorgvoorkansen. $\mathrm{nl} /$ samen-kansrijk-en-gezond/.

gedachte is dat activiteiten dan beter aansluiten bij de leefwereld van een doelgroep. In het programma leerde het fonds werkenderwijs over wat wél werkt om gezinnen in achterstandssituaties te bereiken, erbij te betrekken en te binden. Een eerste beginsel in alle projectvoorstellen binnen het programma Gezonde toekomst dichterbij was dat de doelgroep moest participeren. Een van de subsidierondes kende een voorfase waarin subsidie werd verstrekt om met bewoners samen een plan te maken. Het plan kon vervolgens met een vervolgsubsidie ook worden uitgevoerd. Deze plannen bleken uiteindelijk zeer succesvol in de uitvoeringsfase in het bevorderen van de participatie van bewoners.

Het programma wilde dat niet alleen in de toegekende projecten ruimte was voor participatie, maar dat ook mensen in een achterstandssituatie aan het programma zouden deelnemen. Daartoe is een klankbordgroep in het leven geroepen. Het fonds vroeg twee participatie-experts (de eerste en de laatste auteur) om hulp en advies. Een van hen (de eerste auteur) trad op als facilitator van de dialoog tussen de ervaringsdeskundigen en de medewerkers van het fonds. Dit kreeg vorm op basis van de uitgangspunten van participatief actieonderzoek en is ook vanuit dat kader geëvalueerd $[4,5]$.

\section{Proces: nodig uit en omarm het verschil}

Het programma Gezonde toekomst dichterbij was gericht op het verbeteren van de gezondheid van gezinnen in een achterstandssituatie. Het profiel van een ervaringsdeskundige voor de klankbordgroep was dan ook 'een persoon met weinig inkomen, weinig opleidingsniveau en thuiswonende kinderen'. Deze werd geworven in het netwerk van 'sleutelfiguren' van de participatie-experts in Amsterdam en omstreken. Dit laatste gebeurde om een drempel tot deelname aan de bijeenkomsten weg te nemen, die in Amsterdam bij FNO plaatsvonden. Er werden vijf ervaringsdeskundigen geworven voor de klankbordgroep. Twee ervaringsdeskundigen voldeden niet helemaal aan het profiel: de één had een hbo-opleidingsniveau en de andere had een kind dat bijna het huis uitging. Het fonds besloot het profiel niet rigide toe te passen. Juist vanwege de aanvullende perspectieven bleek dat een waardevolle keuze.

'Wij hadden soms meer een brugfunctie tussen dat wat gezinnen in armoede meemaken en de "systeemwereld" met beleidstermen en rapportages. Wij kunnen in beide werelden meepraten.' (ervaringsdeskundige)

De vijf ervaringsdeskundigen die als vaste klankbordgroep deelnamen, hadden diverse achtergronden.

'Onze les is dat het net zo belangrijk is om te kijken naar aanvullende kwaliteiten en persoonlijkheden binnen een groep, als naar strikte kenmerken. De verschillende achtergronden maakten dat we de moeders op verschillende manieren konden betrekken, afhankelijk van hun kracht en motivatie.' (FNO-medewerker)

Er was natuurlijk ook verschil tussen de leefwereld van de mensen met ervaringskennis en die van de medewerkers van het fonds. Eerstgenoemden beschikken vaak niet of in minder mate over financiële, sociale en culturele hulpbronnen om gezond te leven. Na het eerste jaar kwam dit in de evaluatiegesprekken aan de orde.

De vijf ervaringsdeskundigen adviseerden gevraagd en ongevraagd over de koers en activiteiten van het programma Gezonde toekomst dichterbij. Daarnaast hadden ze een adviesrol voor de 46 projecten die vanuit het programma ondersteund werden. De projectleiders konden hen vragen voorleggen over het bevorderen van de participatie van bewoners in hun project. In totaal vonden er in drie jaar vijftig maandelijkse groepssessies plaats. Daarnaast gingen de ervaringsdeskundigen mee op werkbezoek bij projecten en fungeerden ze als copresentatoren of workshopbegeleiders op congressen. In totaal zijn de ervaringsdeskundigen op 23 momenten op pad geweest met medewerkers van het fonds. Ten slotte vond jaarlijks via een-op-een gesprekken met de ervaringsdeskundigen een evaluatie plaats.

\section{Lessen tijdens het proces}

\section{Ruimte voor de ander is niet vanzelfsprekend}

Alle ervaringsdeskundigen hadden ervaring met leven in armoede en ontwrichtende gebeurtenissen in het verleden of heden. Dit verbindt de ervaringsdeskundigen onderling en geeft emotionele herkenning, maar leidt soms ook tot fricties die de onderlinge dialoog tussen de ervaringsdeskundigen bemoeilijkten. Deze dialoog was nodig om samen te leren en te komen tot een gedeelde visie op het programma en feedback te geven aan het fonds. Een van de ervaringsdeskundi- 
gen gaf aan dat er soms geen ruimte is voor anderen als je in een ingewikkelde situatie zit.

'Je staat dan in een overlevingsmodus waarin empathie voor de ander moeilijk op te brengen is.' (ervaringsdeskundige)

Verschillen in uitdrukkingsvaardigheden bepaalden soms de mate waarin de ervaringsdeskundigen begrip voor elkaar konden opbrengen. Dit leidde af en toe tot ongemakkelijke situaties, waarin niet iedereen zich gehoord, gezien en gesteund voelde. Het is belangrijk dat de facilitator van de onderlinge dialoog hier oog voor heeft, zodat de groepsdynamiek benoemd en gekanaliseerd kan worden.

'Ik voelde in veel bijeenkomsten spanningen tussen de deelnemers, vooral in plenaire gesprekken. Echter opvallend was, dat iedereen al die jaren altijd aanwezig was. Dit bevestigt voor mij waarde van de aandacht voor relationele dynamieken en de waarde die de moeders hechten aan hun rol.' (facilitator)

\section{Focus op concrete producten en creatieve werkvormen}

Om ruimte te scheppen voor de ervaringen en emoties van de ervaringsdeskundigen en negatieve groepsdynamiek te doorbreken was een creatieve aanpak nodig. Niet alles laat zich immers uitdrukken in taal en niet iedereen is talig. Bovendien werd al snel duidelijk dat de gebruikelijke overlegstructuren, zoals een vergadering, de participatie belemmerden. Succes werd geboekt wanneer in verschillende vormen en contexten, zoals verschillende groepjes, aan concrete producten werd gewerkt. Zo resulteerde het adviseren van de projectleiders over manieren waarop zij bewoners beter bij hun projecten kunnen betrekken in het samenstellen van de gids Participatie van ouders in integrale gezondheidsaanpakken [6]. Hun adviezen konden via deze gids ook breder worden verspreid.

Ook het cocreëren van een boekje dat de leefwerelden van de ervaringsdeskundigen visueel in kaart bracht, sloeg aan bij de ervaringsdeskundigen. Met behulp van de methode van Photovoice boden zij een inkijk in hun wereld, ervaringen en behoeften via het boekje Je ziet het niet [7]. In deze uitgave roepen zij professionals en beleidsmakers op om het over een andere boeg te gooien. Deze oproep vormt mede de basis voor het verdiepende programma 'Samen Kansrijk en Gezond' van het fonds, dat ook gericht is op het verminderen van gezondheidsachterstanden en in 2021 van start is gegaan.

Ten slotte werden via diverse werkvormen eindrapportages van projecten uit het programma samen besproken vanuit het perspectief van ervaringsdeskundigen. $\mathrm{Na}$ analyse van al deze uitspraken ontstond een criterialijst (zie supplement 1), die gebruikt kan worden voor het beoordelen van projectplannen vóór en mét deze doelgroep. Deze is tevens bewerkt tot een beoordelingsformulier (zie supplement 2), met criteria voor subsidieaanvragen in het nieuwe programma 'Samen Kansrijk en Gezond' [8].

'De moeders hebben veel meer bijgedragen dan de rol van een klankbord. De samenwerking leverde ons ook een stevige basis op voor het vervolgprogramma.' (FNO-medewerker)

\section{Waarde van de betrokkenheid van de ervaringsdeskundigen}

Het samenwerken met een groep ervaringsdeskundigen levert meer op dan alleen inzicht in de problemen waar de doelgroep tegenaan loopt. De samenwerking verrijkte het beleid van de organisatie op diverse manieren. Zo geeft FNO in alle programma's vertegenwoordigers van de doelgroep een grote invloed bij het vormgeven van programma's en projectaanvragen. Er wordt gewerkt met vaste panels van ervaringsdeskundigen, die een zwaarwegend advies geven in de toekenning van projectaanvragen. Hun oordeel telt even zwaar als dat van de programmacommissie van experts. Bovendien kiest FNO ervoor om de vertegenwoordigers van de doelgroep ook een stem te geven in gesprekken met beleidsmakers en politici. Hiertoe investeert FNO in de ervaringsdeskundigen door hen trainingen te geven, bijvoorbeeld gericht op lobbyen.

Voor het programma Gezonde toekomst dichterbij vormden de ervaringsdeskundigen een goede spiegel voor de professionele ambities van FNO. Er spelen soms zoveel problemen dat gezondheidsverbetering laag op de prioriteitenlijst staat.

\section{Empowerment}

Hun inzet leverde de ervaringsdeskundigen verschillende opbrengsten op. Een van hen gaf aan het vooral belangrijk te vinden dat ze haar verhaal en dat van anderen naar buiten kan brengen. Dat ernaar geluisterd wordt en dat het meegenomen wordt in beleid van FNO.

'Je wereld wordt daarmee ook weer een beetje groter dan die van je woonkamer en tv. Ik voel dat ik erbij hoor. En dat voelt goed. Ik doe iets nuttigs in de maatschappij!' (ervaringsdeskundige)

Ook maakte de groep niet alleen contact met andere ervaringsdeskundigen mogelijk, maar ook en vooral met mensen die ze normaal niet zomaar ontmoeten, zoals projectleiders uit het hele land.

'Doordat ik meedoe, krijg ik inzicht in de wereld van de ander. Dit is leerzaam, want je ziet en hoort hoe mensen omgaan met hun leven, hun geld en hun kinderen. Dit zou je anders niet zomaar van elkaar zien en horen.' (ervaringsdeskundige) 


\section{Conclusie: vanaf de start samen bouwen aan een partnerschap}

Wanneer je als fonds of andere organisatie activiteiten wilt ontwikkelen, is het belangrijk de doelgroep bij de activiteiten te betrekken. Onze belangrijkste les daarbij is: neem de mensen op wie je programma of beleid gericht is zo vroeg mogelijk mee bij het opstellen en reflecteren op de kaders van het programma. Door ervaringsdeskundigen erbij te betrekken en gebruik te laten maken van hun talenten, kunnen mensen groeien. Niet iedereen heeft de talenten en mogelijkheden om stukken tekst te beoordelen, maar ook andere werkvormen kunnen abstracte onderwerpen inzichtelijk maken en negatieve groepsdynamieken constructief ombuigen. Ook gezamenlijke werkbezoeken van een ervaringsdeskundige en een medewerker hebben een positief effect. Het is belangrijk dat de facilitator of gespreksleider oog heeft voor de groepsdynamiek. Een jaarlijks een-op-een evaluatiegesprek kan inzicht geven in ieders ambities en talenten. Wederzijds vertrouwen is een voorwaarde voor een goed partnerschap en maakt langdurige relaties mogelijk, waarin alle betrokkenen zich kunnen ontwikkelen.

Open Access This article is licensed under a Creative Commons Attribution 4.0 International License, which permits use, sharing, adaptation, distribution and reproduction in any medium or format, as long as you give appropriate credit to the original author(s) and the source, provide a link to the Creative Commons licence, and indicate if changes were made. The images or other third party material in this article are included in the article's Creative Commons licence, unless indicated otherwise in a credit line to the material. If material is not included in the article's Creative Commons licence and your intended use is not permitted by statutory regulation or exceeds the permitted use, you will need to obtain permission directly from the copyright holder. To view a copy of this licence, visit http://creativecommons.org/licenses/by/4.0/.

\section{Literatuur}

1. DeddingC, Slager M.Derafels van participatieindegezondheidszorg. Van participerende patiënt naar participerende omgeving. Amsterdam: Boom; 2013.

2. Visser V. Lager opgeleiden voelen zich te min om te participeren in burgerinitiatieven. 2019. https://www. socialevraagstukken.nl/lager-opgeleiden-voelen-zich-temin-om-te-participeren-in-burgerinitiatieven/. Geraadpleegd op: 12 mei 2021.

3. SchakelW, Plas Dvan der. Degrees of influence: educational inequality in policy representation. Eur J Polit Particip. 2020;60(2):418-37.

4. Abma T, Banks S, Cook T, et al. Participatory research for health and social well-being. Cham: Springer;2019.

5. Abma T. Responsive evaluation: its meaning and special contribution to health promotion. Eval Progr Plan. 2005;28(3):279-89.

6. Klankbordgroep. Gezonde toekomst dichterbij. Participatie van ouders in integrale gezondheidsaanpakken: tips voor professionals. 2018. https://www. fnozorgvoorkansen.nl/afgeronde-programmas-fno/ gezonde-toekomst-dichterbij/klankbordgroep/. Geraadpleegd op: 12 mei 2021.

7. Klankbordgroep. Gezonde toekomst dichterbij. Je ziet het niet. 2019. https://www.fnozorgvoorkansen.nl/ afgeronde-programmas-fno/gezonde-toekomst-

dichterbij/klankbordgroep/. Geraadpleegd op: 12 mei 2021.

8. FNO. Samen Kansrijk en Gezond.. https://www. fnozorgvoorkansen.nl/samen-kansrijk-en-gezond/. Geraadpleegd op: 12 mei 2021.

9. Vaandrager L, Hogeling L, Crijns C, et al. Overkoepelend evaluatieonderzoek Gezonde toekomst dichterbij: eindrapportage. Wageningen: Wageningen University \& Research, Gezondheid en Maatschappij; 2020.

10. Groot, B.; Abma, T. Participatory health research with mothers living in poverty in the Netherlands: pathways and challenges to strengthen empowerment. Forum Qual Social Res. 2020 Jan 28;21(1):1-22. 